\title{
Reviewer Acknowledgements for Global Journal of Health Science, Vol. 13, No. 3
}

Global Journal of Health Science wishes to acknowledge the following individuals for their assistance with peer review of manuscripts for this issue. Their help and contributions in maintaining the quality of the journal are greatly appreciated.

Global Journal of Health Science is recruiting reviewers for the journal. If you are interested in becoming a reviewer, we welcome you to join us. Please contact us for the application form at: gjhs@ccsenet.org.

\section{Reviewers for Volume 13, Number 3}

Abiodun Adeniran, University of Ilorin, Nigeria

Ama Pokuaa Fenny, University of Ghana, Ghana

Angel Alfonso Velarde Lopez, University of Pennsylvania, Guatemala

António Calha, Polytechnic Institute of Portalegre, Portugal

Ayesha Johnson, University of South Florida, United States of America

David Otieno Odongo, Masinde Muliro University of Science and Technology, Kenya

David Richard Walwyn, University of Pretoria, South Africa

Farahnaz Amini, UCSI University, Malaysia

Fathi Shamma, The Arab Academic College Israel Haifa, Israel

Jose R Cordon, Universidad de Cadiz, Spain

Le Thi Thanh Xuan, Hanoi Medical University, Viet Nam

Marcel Wullschleger, University of Bern, Switzerland

Meng Zhao, Texas A\&M University at Corpus Christi, United States of America

Pedram Iranmanesh, Dentist, Independent Researcher, Iran

Pi-Ming Yeh, Missouri Western State University, United States of America

Polly Yeung, Massey University, New Zealand

Robert Sloan, Kagoshima University Graduate School of Medical and Dental Sciences, Japan

Samir Othman, Hawler Medical University, Iraq

Santha James, Australian Catholic University, Australia

Soon Soo Hoo, Royal North Shore Hospital, Australia 